\title{
Retracing the Direct Method in Spain amongst English manuals \& the historical press (1900-1950): Supporters and opponents
}

\section{Alberto Lombardero Caparrós}

\section{(2) OpenEdition \\ 1 Journals}

Electronic version

URL: https://journals.openedition.org/dhfles/7540

DOI: $10.4000 /$ dhfles.7540

ISSN: 2221-4038

Publisher

Société Internationale pour l'Histoire du Français Langue Étrangère ou Seconde

Printed version

Date of publication: 1 December 2020

Number of pages: 281-297

ISSN: 0992-7654

Electronic reference

Alberto Lombardero Caparrós, "Retracing the Direct Method in Spain amongst English manuals \& the historical press (1900-1950): Supporters and opponents", Documents pour l'histoire du français langue étrangère ou seconde [Online], 64-65 | 2020, Online since 02 February 2021, connection on 27 March 2023. URL: http://journals.openedition.org/dhfles/7540 ; DOI: https://doi.org/10.4000/dhfles.7540

This text was automatically generated on 27 March 2023.

All rights reserved 


\title{
Retracing the Direct Method in Spain amongst English manuals \& the historical press (1900-1950): Supporters and opponents
}

\author{
Alberto Lombardero Caparrós
}

\section{Introduction}

1 The good winds in foreign language teaching coming from Northern Europe in the guise of the Reform Movement reached Spain converted into a breeze. Since the first documented reference in 1904 until the last in 1945, one mainstream methodology dominated the growing Spanish market of foreign language teaching and learning in Spain: The Grammar-Translation method. However, by the turn of the nineteenth century the foreign language market was widening in terms of novel methodologies. Such is the case with the Direct Method, heralded by a group of European linguists, most of them English teachers such as Wilhelm Viëtor, Paul Passy, Henry Sweet and Otto Jespersen, just to name a few.

2 Research into the DM in Spain has been scarce. One of the first references can be found in Aquilino Sánchez (1992). He mainly focuses on the description of the DM as a natural method and on the teaching of Spanish as a foreign language. Viña Rouco (2009) delves into the Free School ${ }^{1}$, a private institution with foreign language teaching methodologies similar to those of the DM as far as foreign language teaching and learning is concerned. Rius Dalmau (2016) explores the Free School's foreign language teacher training, which included some stays abroad to further their studies. Lombardero (2019) sheds some new light on some of the English manuals which adopted a DM stance. We would like to finish this brief bibliographical account by mentioning a recent publication, coordinated by Dr Bascuñana (2017), on the history of French language teaching in Spain. It not only refers to the DM but it has become a 
seminal work for anyone interested in the evolution of foreign language teaching, especially that of the French language, in Spain over the last centuries. Despite these works, much is yet to be investigated. In particular, for example, first-hand accounts of what was going on in actual English classrooms of the time, a hard-to-meet objective due to the scarcity of sources, the role played by private academies towards the DM, the DM and its presence in the scientific literature of the time; and, in general, allencompassing, interdisciplinary studies on the DM and its presence in French, English, German, and Italian manuals.

3 This article intends to provide a descriptive analysis as a theoretical and methodological tool applicable to the historiography of foreign language teaching and learning in Spain. In order to do so, from a synchronic standpoint, we rely principally on English manuals but, at the same time, we widen our scope by including the historical press and some institutions that contributed to a weak presence of the DM in Spain. Therefore, the chosen period of research in this article is the result of my research findings on the presence of the DM in Spain. Two sources have been used. First, a thorough search of the Spanish historical press; in particular, in two of the most comprehensive online repositories: the Hemeroteca Digital of the National Library of Madrid $^{2}$ and the Biblioteca Virtual de Prensa Histórica ${ }^{3}$ run by the Spanish Government. Our aim is to seek any evidence on the presence of the DM in terms of opinion articles, advertisements and manual reviews in the national press. Second, an analysis of the English manuals which, one way or another, mentioned the DM either favorably or negatively in their paratexts. Having considered these two variables, we can surmise that the DM became a subject worthy of some discussion in Spanish between 1904 and 1945; that is, since the earliest reference to the DM found in the historical press and the publication of Curso completo de lengua inglesa by the priest, Román Torner, first published in 1945 and re-printed several times until the early 50s. The advent of Audiolingualism in the mid-fifties in Spain shunned any sort of presence of the DM both in the historical press and the manuals published, thus indicating its inexistent presence in the English language teaching and learning arena. Hopefully, future studies will provide a much fuller picture of the real impact that the DM exerted in foreign language teaching during the first half of the twentieth century in Spain.

During the period object of study, the French language ranked first as the most studied foreign language amongst Spaniards followed, at some distance, by the English language which was to gain more prominence as the twentieth century went by (Lombardero: 2019).

5 The methodology in question that was in vogue in that period was the so-called Grammar-Translation Method. That is, a deductive approach which consisted of cramming students with grammar rules and lists of vocabulary. The intended goal was a literary one and, for those purposes, it worked. However, this methodology failed when oral practice was involved. Amongst the manual writers consulted for this study, a significant number advocated an Eclectic Methodology which combined the study of grammar with a more varied array of exercises such as gap-filling, paraphrasing, and so on, in addition to translation. In a nutshell, that eclecticism would look like nothing more than a spin-off of the Grammar-Translation method, which is partly true. The whole truth lies in the fact that a reduced number of authors and institutions also understood their eclectic methodology as a combination of the Grammar-Translation Method with the DM, thus becoming somewhat receptive towards some of the tenets of 
the DM as we shall see. Therefore, the following study will focus on the tripartite nature of the DM in Spain according to the manuals and periodicals consulted 4 : opponents, supporters, and the eclectic solution.

6 Last, a final word on the term 'Method' is deemed necessary. I regard 'Methods' as 'packages' and things have never been like that. The reality of the term lends itself to a more eclectic interpretation and definition.

\section{Opponents}

7 There are four manual authors who expressed their opinions against the DM, never referring to it as 'Direct' but by using other euphemisms as we shall briefly see. A common characteristic of this group entails the fact that their manuals were all used as secondary school textbooks having been previously approved by the Ministry of Education although one was the standard textbook used in a private academy too.

8 Chronologically, the first author is Raoul Massé (1877-1963) who opened a private academy in Barcelona in the 1905 called the International Institute and which was later to become the 'Academia Massé' ('Academy Massé') and then 'Escuelas Massé' (Massé Schools), functioning also as an editorial house.

9 For the teaching of languages, Massé implemented the 'Método Massé-Dixon's. Both he and F. G. Dixon ${ }^{6}$ were English teachers at the Academia Massé. Their English course material consisted of three manuals from elementary to advanced levels whose titles changed depending on the editions, most of them undated. The manuals were very popular for 50 years, between the 1910s and 1950s. They all bore a top imprint on the cover referring to the Método Massé-Dixon and only the name of Dixon in the case of the English manuals.

10 A closer look at the paratexts, and in particular to the prefaces of different editions shows that Massé and Dixon held the same views on language teaching over time. They referred to their method as práctico not in the modern sense of 'useful' but in the sense that it provided some exercises to practice. Hence, they make no reference to the spoken language dedicating the lion's share of their method to reading skills.

11 As for the direct method, there are two references in their prefaces which demonstrates their contempt towards it, thus disregarding it as a well-grounded teaching or learning methodology. The first reference is the most explicit and best depicts their straightforward criticism against the DM: 'ausencia absoluta de gramática $y$ ejercicios en ciertos métodos llamados 'directos' ('total absence of grammar and exercises in certain methods called 'direct') (Dixon, $6^{\text {th }}$ edition:5). The absence of grammar became one of the main criticisms against the DM in a country like Spain which advocated, as mentioned earlier, a more traditional approach mainly based on the study of grammar.

12 The last reference in their prefaces against the DM is more implicit. It relates to reading skills and the use of intuition: 'la traducción de términos abstractos por intuición puede conducir a errores' (translation of abstract terms by intuition may lead to errors) (Dixon, $6^{\text {th }}$ edition:5-6). Massé and Dixon regard intuition negatively, as a cause for error making, thus rejecting one of the principles of the DM which, in fact, promoted the study of grammar intuitively.

13 Our second account comes from Lewis Th. Girau ${ }^{7}$ whose real name was Lluís Girau. He wrote a two-volume English manual called Método de Inglés first published in the 1920s. 
It became highly successful based on the number of reprints it had, especially his Libro Primero or first course which reached its $26^{\text {th }}$ reprint in 1954. In the preface to his Método de Inglés, which did not change in any of its reprints, Girau openly states his anti-Direct Method views and, unlike Massé and Dixon, never mentioning the term 'Direct Method'. We have consulted two editions of his first book, those of 1937 and 1954, and the prefaces are the same. Girau calls his method a 'método mixto' (1937:13) which combined succinct theory with ample practical material or exercises.

Girau also refers to other methods without naming them although everything leads to the conclusion that the DM is behind his bitter criticism against them.

[...] existen otros [métodos] que, si bien de carácter más moderno, contienen numerosas imperfecciones que no invitan a admitirlos. (1954:6)

Though a reference to the DM is vague in the above-mentioned quotation, the mentioning of its being 'modern' may fall under the umbrella of the DM. However, further on in Girau's preface there is a more explicit reference to the DM: 'Gravisimo error pedagógico es considerar la práctica como base de estudio e inducir de ella reglas $y$ preceptos.' (1937:10) (It is a most serious pedagogical error to regard practice as the basis of study and induce rules and precepts from it). The key word that reeks of DM from the above-mentioned quotation is 'induce', one of the cornerstones of the DM, especially when it came to teaching grammar. Furthermore, Girau goes on to explain the bad effects of following such a modern and inductive methodology by stating that it is contrary to logic, makes a varied use of teachers, causes reluctancy to learn a language, and may even lead to students giving up learning the language. All in all, Girau proposes a 'método mixto' (1937:13). For Girau, one learns through study and he rejects the idea, close to his opinion about the DM, that one can learn without study. That is, just by speaking or practising the language orally.

16 Towards the end date of our period of study, the priest Román Torner Soler wrote his Curso completo de lengua inglesa, a course divided into two books the first published in 1945 and the second one year later. It must have been quite successful since it was approved as an official textbook in high schools by the Ministry of Education in 1946 and its second edition in 1948 had a circulation of ten thousand copies. Interestingly enough, prior to its publication it had been approved by a censor from the Spanish Church due to the strict control the Church exerted on Spanish public life ${ }^{8}$.

On the front page, Torner indicated that he had formerly been a teacher of the Abele Groove School in Epsom, England. At the time he published his coursebook he was a professor of English at the National Institute of Secondary School in Bilbao. In his preface, Torner refers to the DM in the following manner: El método directo resulta de hecho impracticable (The direct method turns out to be impracticable) (1950:Preface) although he does not explain why. His methodology falls between two extreme trends that existed at the time, the DM and the so-called English grammars. He advocated a combination of a gradual exposure of the grammar rules with some phraseological exercises and readings but failed to give that methodology a specific name.

Our final opponent, Jacinto Verdaguer Travesi, made no direct mention of the DM. He implicitly referred to it in the phrase 'los métodos sin gramática son más tentadores' (1938:iv) (the methods without grammar are more tempting). Therefore, he stuck to what he called a grammar method but rejected that such a method bore any similarity to dead languages which some authors still advocated at the time and was the norm in previous centuries. His two-book course called Gramática inglesa became 
very popular in the late 1930s and 1940s, especially in Palma de Mallorca where he worked as an interim teacher of English both at the Commerce School and the National Institute of that city.

\section{Supporters} together with his wife, whose first name has been lost to history, in Valencia in the 1920s. His manual for the teaching and learning of English was titled How to speak, and to write a modern language. The second edition of the New Scientific and Conversation Method was published in 1924, as a first edition has not been found despite a thorough search. Simian, according to his manual's front title, was formerly professor of the National Schools of France ${ }^{9}$ and of the Alliance Française at Barcelona and, at that time, the general manager of the Institut Simian, his language school in Valencia. Other languages such as French and Italian were also taught as well as accountancy and other commerce-related subjects. particular, between 1920 and 1926 according to the local press of Valencia that included a small advertisement of Simian's school throughout that period. Therefore, we solely rely on his manual to find some key evidence on the presence of the DM in Spain.

In the introduction to Simian's manual he overtly states that 'all methods are excellent' (1924:3). Simian is aware of the different purposes for studying foreign languages: to translate, to understand foreign literature, and so on. However, when it comes to speaking, he takes a more definite position: 'It is impossible to know how to speak a language unless conversation is practiced' (1924:4). To modern eyes this may look very obvious but let us remember that the majority of manuals published in Spain at that time advocated a more passive approach to foreign language teaching by fostering the study of grammar and translation as the sole practice possible. Simian breaks away from tradition and becomes the only manual writer in Spain who openly embraced the tenets of the DM and applied them in his manual. Hence, he names his method scientific and conversational. Furthermore, there is an introductory section in his manual called 'A few useful hints' which is nothing but a vivid argument of the benefits the DM could bring forth much in the same line as Reformers like Sweet, Jespersen and Passy, among others, had been postulating in their writings. In a nutshell, Simian's hints, in their original, are the following:

\footnotetext{
1. [...] this book is written according to the DM which consists in associating the word with the object and to avail himself of the meaning of the words already known in order to discover that of the unknown words without translating the same, which I expressly forbid.
}

2. The pupil ought only to hear and to speak in the language he is learning. 
3. The lessons must be taken with the book closed.

4. The exercises at the end of each chapter should be done orally, the book of the pupil must be closed.

\section{Put in the plural the following exercises:}

1. The book. -2 . The copy-book. -3 . The pencil. -4 . The penholder. -5 . The wall. -6 . The room. -7 . The table. -8 . The inkstand. 9. The ruler. -10 . The rubber. -11 . The clock. -12 . The chair. -13 . The bookcase. -14 . The armchair.

\section{- Exercise № 2}

Put in the singular the following exercises:

1. The tables. -2 . The chairs. -3 . The armchairs. -4 . The penholders. -5 . The bookcases. -6. The inkstands. -7 . The books. -8 . The rubbers. -9 . The pencils. -10 . The pens. -11 . The blackboards. -12 . The canapés. -13 . The copy-books. -14 . The walls.

- Exercise № 3

Put in the plural the following exercise:

1. The pencil is on the table. -2 . The pencil is not on the table, it is in the pocket. -3. The bookcase is in the room. [...]. -10. The chair is under the table.

- Exercise $\mathrm{N}^{\circ} 4$

Put in the singular the following exercise

1. The rulers are not under the table, they are on the table. -2 . The pencils are on the table. -3. The penholders are on the table and the pencils are in the pocket. [...]. -10. The inkstands are on the table.

\section{READING AND RECITATION № 1}

In the room there are six chairs, two armchairs, a sofa, a table and a bookcase. The pencils, the penholders, the copy-books are on the table. The books are not on the table, they are in the bookcase. The blackboard, the calendar and the clock are against the wall.

Answer the following questions:

1. How many chairs are in the room? -2. Are there three armchairs in the room? -3. Is the bookcase in the room? -4 Where is it? -5 . Are the chairs in the room? -6 . Where are they? -7. Are the books in the bookcase? -8. Where are they? -9. Where is the calendar? -10 . Where is the clock? -11. Is the bookstand on the table or on the chair? -12. Are the chairs under the table? -13. Are the copy-books on the table? -14. How many are there? -15. Is the rubber on the table or in the pocket? -16 . Are the pupils in the room? (Simian, 1924:16-17)

The historical press has shed some light regarding the target students who might have attended the Simian Institute. According to an ad in the local press called Las Provincias, which is one of the first found, the Institut Simian advertised courses as follows:

Documents pour l'histoire du français langue étrangère ou seconde, 64-65 | 2020 
Institut Simian (De Idiomas)

Clases colectivas y particulares de francés, inglés para correos, telégrafos, aduanas, ingenieros, estadística, consulado, carreras diplomáticas, etc. Sistema a viva voz. Resultados sorprendentes, inmediatos y permanentes.

(Las Provincias, Diario de Valencia, 7 Septiembre 1921, 3)

Simian, or to be more precise, the Simians since Madame Simian taught French classes to women at the Institut. She is referred to as an 'eminente filóloga' (prominent philologist) and a teacher of French ${ }^{10}$. The ads continued until 1927. From then on, nothing is known about the continuity of a school that will always be remembered as one of the first private schools to implement the DM, apart from the Berlitz Schools but that is another story.

History has it that our next manual was also published in 1924, this time in Barcelona, and written by Pompeu Fabra (1868-1948), considered by many as the father of the modern Catalan language. His Gramàtica anglesa stands as one of the most modern of its time as it included a first part, which almost takes up half the content of the manual, fully dedicated to phonology. Furthermore, it uses a figurative pronunciation very close to the IPA standards. It is here where one finds links to the DM methodology, especially in the treatment of English pronunciation. Let us remember that some of the members of the Reform Movement were phoneticians themselves (Passy, Sweet, Eduard Sievers, etc.).

Fabra's Gramàtica became the first English grammar written in Catalan; that is, mostly directed to a Catalan audience. He is also author of a French grammar published in 1919. His English grammar is divided into two parts, the first on phonology and the second on morphology and syntax. This latter part follows a more traditional pattern as it follows the classical classification of the parts of sentences. The great innovations in morphology took place in the 1930s and in syntax in the 1950s and that is why I consider Fabra's part on phonology as the real innovation in his manual. Apart from following the IPA, his phonetic transcriptions were supported by Daniel Jones (1917) English Pronouncing Dictionary (Wheeler 2006: 643). Another outstanding aspect of Fabra's grammar is the abundant number of examples given to describe English sounds.

Fabra's English grammar has no preface, prologue, introduction, bibliography nor references to the sources he must have used. However, Wheeler (2006) points out the fact that Fabra, who was a self-taught linguist while working as an industrial engineer, was very familiar with the works of Sweet and Jespersen. Fabra commended Jespersen's (1923) The Growth and Structure of the English Language and was a regular reader of the Reformers' books held at the Library of Catalonia which he often attended.

There is no evidence on the real impact of Fabra's English grammar. It is an oddity amongst the increasing number of English manuals published at the time for its innovatory way of describing English sounds. Rather than for students, except advanced ones, his grammar seems more suitable for English teachers who may have needed to broaden their knowledge of English phonetics. The fact that it was published only once may account for its little or scarce impact at a time when more traditional grammars were still in vogue.

Now we turn our attention to two institutions that embraced the DM methodology as part of their curricula. The first is the Free School, founded in 1876 by a group of dissident university lecturers led by Francisco Giner de los Ríos (1839-1915). They had quit their jobs on the grounds they had been deprived of their academy liberty and 
decided to set up a private institution for primary and secondary education as well as for teachers' training. They all had advanced ideas on education and, therefore, in foreign language teaching. They published a monthly bulletin called BILE (Boletín de la Institución Libre de Enseñanza), which proved to be a highly efficient tool to promote the new trends on education worldwide amongst Spaniards. Whith regards the DM, BILE included articles by eminent linguists such as Michael Bréal, José de Caso, Otto Jespersen, Rubén Landa, etc. They all advocated a scientific study of languages based on the study of phonetics and an intuitive methodology for lexis and grammar.

The Free School funded teachers-to-be by means of stays abroad to familiarize themselves with other European teaching traditions. Rius Dalmau (2016:132) mentions the case of one of these future teachers, Dolores Sacristán y Colás. She was a researcher consecrated to the teaching of English. In her final memory she draws a few conclusions on the direction foreign language teaching should take. They bear a striking resemblance to the tenets of the DM: the need for oral practice, perform inclass plays or role-play as it is known today, the practice of pronunciation and rhythm, and with both articulation and pronunciation rely entirely on the teacher. Another grant holder mentioned by Rius Dalmau (ibid.:135) is Pedro Fernández González. He recommended following the precepts of the modern trends, such as to get rid of translation and to develop conversation. To sum up, the Free School aimed at overcoming the logical-descriptive approach to foreign language teaching by applying a new perspective revolving around communicative aspects, the use of language.

The last institution that partially embraced the DM in its curriculum was the Escuela Central de Idiomas (Central School of Languages) in Madrid. Unlike the Free School, it was state-run and dependent on the Central University of Madrid, thus becoming the first official institution that followed a DM methodology although, as we shall see, only partially. Founded in 1911, it was an institution open to everyone, no matter age or job, and which could be combined with working days. Like the Free School, it also trained foreign language teachers-to-be. The first languages to be taught were English, French, and German in three courses plus an additional one. According to its curriculum, the DM was to be applied only in the first course. For the remaining two, the foci were the study of grammar and translation. There was a single final exam called Certificado de Aptitud (Certificate of Competence), which consisted of two parts. The first had two qualifying stages - dictation and writing. The second included two translations, direct and reverse, and a conversation with the tribunal. Since conversation was one of the final exam requirements no doubt the speaking skills played their part in the language classes much like in the rest of the cases presented in this chapter.

\section{Conclusion}

A breeze rather than a storm, like in Frans Wilhelm (2009) for the Dutch tradition. Such was the DM influence in Spain. A somewhat war of methods came into being since the implementation of the Direct Method in official curricula in France in 1900. A methodological war between traditionalists and reformers, between the grammartranslation and the direct method. The impact of this 'war' in Spain was tiny.

The bulk of English manuals produced in the first four decades of the twentieth century in Spain opted for eclecticism (Lombardero 2019), thus combining the study of grammar and translation with the practise of some exercises with no or scarce mention 
of the DM. However, a small sample of DM-prone manuals made their way into the Spanish market, mostly associated with private academies or institutions like the Free School. A school that stands out because the different foreign language teachers working there formed a network of specialists in foreign language teaching and who were for a new approach to foreign language teaching and learning much along the lines of what the DM represented at the time. However, all the English manual writers of the time failed to form any kinds of groups or associations towards an improvement of foreign language teaching.

With the introduction of audio-lingualism in the 1950s, the war raged on amongst more methodologies. By the 1960s, foreign language teaching had still a long way to go. In the Expert Committee of the Council of Europe held in London in 1964 it was agreed that there was a problem with official language exams purely based on the use of translation, thus seeking linguistic knowledge purely literary destined to stress the passivity of the direct translation. They advocated an urgent replacement with other examinations that could assess students' active and oral capabilities (Grandía 1964).

In summary, while the private sector of education sought new ways of implementing the latest advances in foreign language teaching methodologies in Spain; that is, the DM at that time, the official centres were more reluctant to do so. There are several reasons why the DM never caught on in Spain. First, teachers lacked the necessary training on the new methodology. Second, classes were rather crowded and teachers felt more comfortable with the Grammar-Translation method. Last, the Spanish educational legislators of the time, unlike other countries such as France, Russia or Argentina, never gave the DM a chance of becoming the official methodology in foreign language teaching in Spain. As for the small number of English manuals which followed the main precepts of the DM, they never reached a wide circulation in the Spanish market due to the reduced number or reprints or re-editions they had at the time.

The DM was certainly a turning point in the evolution of foreign language teaching globally speaking, whose tenets still echo in today's post-method, communicative era in a globalised world.

\section{BIBLIOGRAPHY}

\section{Sources primaires}

(1921). Las Provincias (Diario de Valencia). Año 56, no16.999. 7 Septiembre, 3. On line: [https://

prensahistorica.mcu.es/es/consulta/

registro.do?id=11000346319]. (Acessed on 14/04/2019).

(1921). Las Provincias (Diario de Valencia). Año 56, nº3652. 28 Septiembre, 3. On line: [https://

prensahistorica.mcu.es/es/consulta/

registro.do?id=11000224209]. (Acessed on 14/04/2019).

ARENAS, Victoriano (1922). Método intuitivo de lengua inglesa hablada. Madrid: Estanislao Maestre. 
MORRIS-ALFRED (1909?). Método teórico-práctico para la enseñanza del inglés. Toledo: Imp. y Lib. De la Viuda é Hijos de J. Peláez.

FABRA, Pompeu (1924). Gramàtica anglesa. Barcelona: Editorial Catalana, S. A.

FABRA, Pompeu (1919). Gramática francesa. Barcelona: Enciclopedia Catalana.

GIRAU, Lewis Th. (1954, 1937). Método de inglés. Barcelona: Escuela Massé.

GRANDIA MATEU, Luis (1964). "El Consejo de Europa abre nuevos derroteros en la enseñanza de las lenguas modernas en los países occidentales”. Revista de Enseñanza Media 141-144, 1369-1378.

JESPERSEN, Otto (1923 [1905]). Growth and Structure of the English Language. New York: D. Appleton and Company.

MASSÉ, Raoul (1923). Método práctico de inglés. Método Massé-Dixon. Barcelona: Escuela Massé.

RIEU-VERNET, Aubin (1900). A modern method of teaching modern languages. Madrid: ArahuetesVilloria.

SIMIAN, A. J. (1924). How to speak, and to write a modern language. New scientific and conversation method. English. First Book. Madrid: Viuda de Miguel Sanchís.

TORNER SOLER, Román (1945). Curso completo de lengua inglesa. Barcelona: Alma Mater.

VAUGHAN, H. Francis (1930). Método práctico para la enseñanza del inglés. Barcelona: Escuela Inglesa Vaughan.

VERDAGUER TRAVESI, Jacinto (1938). Gramática inglesa. Palma de Mallorca: Imprenta Mosén Alcover.

\section{Sources secondaires}

BASCUÑANA, Juan F. García (ed.). (2016). Diccionario de historia de la enseñanza del Francés en España (siglos XVI-XX). Tarragona: Universitat Rovira i Virgili. On line: [http://www.grelinap.recerca. urv.cat/ca/projectes/diccionario-historia-ensenanza-frances-espana/].

LOMBARDERO, Alberto (2019). Two Centuries of English Language Teaching and Learning in Spain. Amsterdam: Amsterdam University Press.

RIUS DALMAU, María Inmaculada (2016). "La enseñanza de las lenguas vivas: vision metodológica de los pensionados de la Junta para la Ampliación de Estudios e Investigaciones Científicas (1908-1935)”. 125-136. In Tomás Gonzalo SANTOS and al. (eds.). Texto, Género y Discurso en el Ámbito Francófono. Salamanca: Ediciones Universidad Salamanca.

SÁNCHEZ, Aquilino (1992). "Historia de la enseñanza del español como lengua extranjera”. Madrid: SGEL, s.a.

VIÑA ROUCO, María del Mar (2009). “Un notable antecedente del enfoque comunicativo en la enseñanza de lenguas extranjeras y de la apertura europeísta en la España de principios del siglo XX: Memoria histórica de la enseñanza de idiomas". Porta Linguarum, 11. On line: [https:// dialnet.unirioja.es/servlet/articulo? codigo $=2786762]$.

WILHELM, Frans (2009). "Breeze or storm? The European Reform Movement and Dutch Foreign Language Teaching, c1880-1920". Documents pour l'histoire du français langue étrangère ou seconde, 43, 163-178. Accessed online on 12/02/2019 at : [https://journals.openedition.org/dhfles/881? lang=en\#quotation] 
WHEELER W. Max (2006). “Introducció a la Gramática Anglesa de Pompeu Fabra”. In Jordi MIR \& Joan SolÀ, (dirs.) (2005-2012). Obres completes de Pompeu Fabra. Barcelona: Enciclopèdia Catalana / Edicions 62/ Edicions 3 i 4/ Moll. Vol. 3, 641-663.

\section{NOTES}

1. The Institución de Enseñanza Libre or Free School in English was a Spanish pedagogical project created in 1876 by Francisco Giner de los Ríos, which entailed the creation of the first state-andreligion-free educational centers in Spain running until its demise in 1936.

2. On line: [http://www.bne.es/ca/Catalogos/HemerotecaDigital/].

3. On line: [https://prensahistorica.mcu.es/es/inicio/inicio.do].

4. For the authors, $c f$. Lombardero (2019). The information from periodicals was gathered via two Historical Press Repositories: The National Library and the Virtual Library of Historical Press of the Ministry of Culture and Sport as mentioned above.

5. At that time, authors' personal methods were quite popular in Spain. Likewise, we mention the Rieu-Vernet Method (1900), Morris-Alfred Method (1909?), Arenas (1922), Vaughan (1930), etc.

6. He is also the author of another English manual published in 1905, entitled Método de Inglés: Curso práctico.

7. His language academy must have become quite famous in Barcelona in the 1920s and 1930s if we are to consider the abundant presence of advertisements found in the historical press of the time.

8. In fact, only the foreign language manuals written by priests were subject to censorship by the Spanish Church. Lay authors' manuals were free from it.

9. We do not know what Simian here means by National Schools (Écoles Nationales, in French) since they do not correspond to any actual institutions in France at that time.

10. Cf. Las Provincias, 28 Septiembre 1921, 4.

\section{ABSTRACTS}

This article surveys the presence of the Direct Method (henceforth, DM), between the first half of the twentieth century in Spain. We will narrow down our study to the particular case of English manuals published in Spain as well as the private and official institutions which were prone to adopt the DM. My purpose, therefore, is to outline some implicit or explicit traces of or references to the DM in manuals, prefaces and other paratexts of the time as well as in some extracts of the historical press. In this regard, we have found some manuals that implemented the DM or 'scientific method', 'conversation method', 'practical method', as it was also known in Spain, thus proving that the DM became a debated topic among some manual writers and intellectuals interested in the study of foreign languages. We can conclude that the DM's presence in Spain is rather scarce in terms of actual English manuals that subscribed to it in contrast to the larger amount of references for or against found in the paratexts of some manuals, in the curricula of some institutions, and in the historical press. 
Cet article examine la présence de la Méthode Directe (MD), pendant la première moitié du XX siècle en Espagne. On limite cette étude au seul cas des manuels anglais publiés en Espagne dans des institutions, publiques ou privées, dans lesquelles on a utilisé la MD. Mon but est de souligner quelques références à la MD dans des manuels et des programmes de certaines institutions. À cet égard, j'ai trouvé certains auteurs de manuels et institutions qui ont accueilli la MD (ou méthode scientifique, méthode de la conversation, méthode pratique, telle qu'elle était aussi connue en Espagne). Je démontre que la MD est devenue un sujet de débat parmi des auteurs et intellectuels intéressés par l'étude des langues étrangères. On peut conclure que la présence de la MD en Espagne est rare dans les manuels anglais, bien qu'elle fasse l'objet d'une grande quantité de références qui lui sont favorables ou bien qui s'y opposent, que j'ai trouvées soit dans les paratextes des manuels soit dans les programmes de certaines institutions, ou dans la presse de l'époque.

INDEX

Mots-clés: méthode directe, Espagne, manuels anglais, partisans, adversaires

Keywords: direct method, Spain, English manuals, supporters, opponents

\section{AUTHOR}

\section{ALBERTO LOMBARDERO CAPARRÓS}

Centro de Educación Superior Alberta Giménez

- alombardero@cesag.org 